\section{The Fable}

\author{
Judith V. Waters \\ Forest Park, Georgia
}

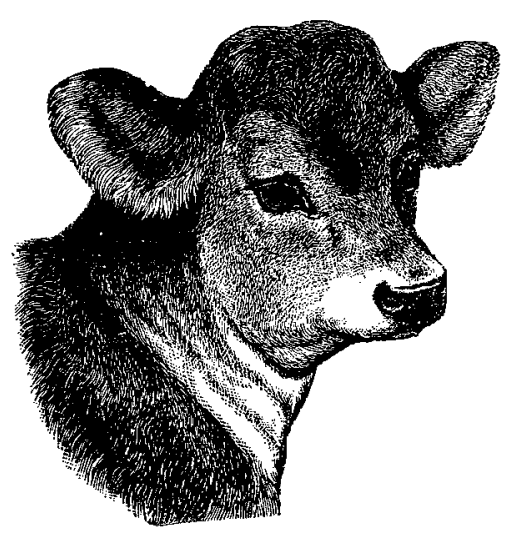

Joshua loved to visit his relatives on the farm. The air was fresh and clear, the water in the pond in the backwoods was clean, there was plenty of room to run and play exuberantly, and at night the only sound was the relaxing music of insects and the occasional call of an owl. Sometimes a whippoorwill would call for hours, or a mockingbird would sing most of the night. Above it all the stars burned like miniature torches, appearing almost within reach.

They would sit outside in the evenings, the adults talking quietly or just listening, the children lying on the cool grass listening and imagining. All of them watched the stars come out; sometimes the great golden globe of the moon rose out of the backwoods, casting a surreal glow over the world, and etching out soft shadows on the grass and in the forest. When there was no moon, they watched the throbbing lights of fireflies flitting in the trees and over the grass; the black sky accentuated the starlight.

It seemed an idyllic existence. There was one disturbing mystery, however, the awareness of which lingered, unacknowledged, in the back of Joshua's mind. Animals had a way of disappearing from the farm between Joshua's visits. Sometimes they disappeared

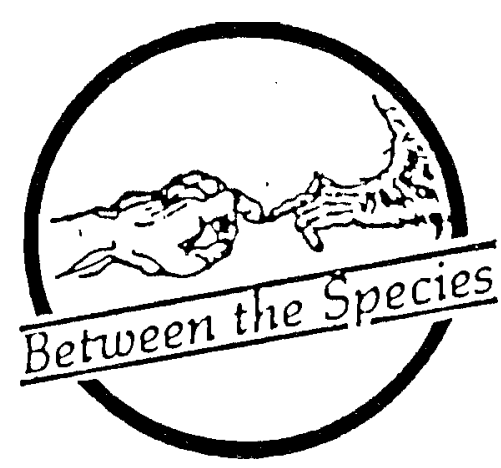

overnight while he was there. No one else seemed to notice, at least no one mentioned it. Joshua himself didn't think directly about it. His mind was filled with joy and fun-with the carefree thoughts that fill a young mind when out of doors in a natural setting and all of life lies ahead as a great adventure.

Joshua loved animals. He loved all of life, so it was inevitable that he would eventually take conscious notice that something was amiss. There was a particularly personable pig living on the farm, named Harold by the children. Harold was only a few days old when Joshua first met him. What made him stand out from all the other piglets was his extreme personableness, even at so young an age, and as he grew his personableness increased. Harold loved the children, and the children loved Harold. They played together. Harold was not only personable, he was gentle and intelligent. Sometimes Joshua and Harold would sit alone together on the grass beside the pond, and Joshua would talk to Harold. Harold would sit close and twitch his ears attentively. Sometimes they just sat quietly and gazed out across the pond.

One day Joshua returned to the farm for another visit. As usual, after politely greeting his human hosts, Joshua went out to speak to Harold. Finding his pen empty, Joshua looked for Harold near the corn crib where he sometimes went for a snack. Harold wasn't there, and he wasn't taking a nap on the grass beside

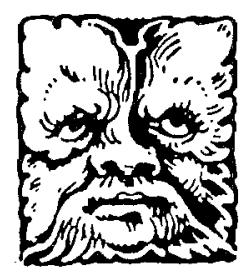


the pond, and he wasn't taking a bath in the stream near the barn. Joshua looked everywhere. Then he went back to the house. "I can't find Harold," he said with concern. There was silence. Everyone looked at him. Then one of the adults said offhandedly, "Well, you know, Joshua, Harold was a grown-up pig, and you know what happens to grown-up pigs." The other children's eyes were sober.

For a moment Joshua didn't understand. He stood there. Suddenly he thought about all the animals who had vanished since he had begun visiting the farm. He thought about the meat counters in the grocery stores at home. He thought about the hearty meals he had shared on the farm. He thought about the meals he ate at home. And he thought about Harold. Joshua felt sick. His knees grew weak and he sat down on the step so that he wouldn't disgrace himself by falling. But his face turned ashen and he broke out in a cold sweat.

For the first time Joshua didn't enjoy his visit. Everyone tried very hard to make him feel better. They were even more thoughtful and kind than usual, and Joshua tried very hard to be cheerful and sociable, but inside he wanted to cry. And there was a deep sense of foreboding gnawing at him-a sense of something alarmingly familiar and yet alien enveloping him. Something that had always been there without his knowing it. Usually Joshua was sorry when the time came to leave the farm, but this time he felt a sense of relief when the visit ended.

At home, he pondered at length on his recent revelation. He understood about predators - they more or less did what they had to do: snakes ate mice and frogs, owls ate rats and birds, foxes ate rabbits and chipmunks. Not pleasant, but somehow in the scheme of things. They had no choice, and they took only what they needed when they needed it. Joshua wondered idly how much of the plethora of meat in the grocery stores ended up being thrown away. With humans it just didn't seem to be the same. It seemed to him that humans had a choice that most animals did not. He knew, too, that humans didn't have to eat meat. He knew this because some of his parents' friends didn't eat meat. A few of them were said to have never even tasted it. Joshua had been to dinner several times at the home of one of these couples with his parents. They were never served beef, or pork, or chicken, or fish, or any other kind of meat. Joshua had not noticed this at the time. It was only after he had heard his parents talking about it later that he thought about it.
A few weeks after Joshua's return home from the farm his grandfather came for a visit. Joshua and his grandfather had always had a close relationship, and it wasn't long before Grandfather asked Joshua what was on his mind. After a brief hesitation, Joshua tried to explain. His grandfather sat listening quietly; he nodded occasionally, and his gentle eyes gazed off into the distance. Grandfather had always been a good listener. After Joshua finished talking, his grandfather sat silently thinking. Joshua sat silently waiting.

Finally, his grandfather spoke. "Joshua," he said slowly, "I am going to teil you a fable the Old People used to tell long ago. It has mostly been ignored and forgotten, but it is about the beginnings of things, and I think you might find it interesting. Perhaps hearing the story will help you to come to terms with what you are feeling." Joshua sat very still. Grandfather began.

Many, many years ago, before there was anything, The Great Omniscience decided to establish a precedent by creating space, objects in the universe, and our own world ex nihiloout of nothing, Joshua. The Great Omniscience cannot be called a 'Being,' because that is of another order of magnitude altogether. It cannot be called 'He' or 'She,' because that too is another order of magnitude. The great Omniscience rises above all categories and labels, and also above all human knowledge and imaginings.

For whatever reasons, The Great Omniscience decided that there should exist something rather than nothing. While people like to think they themselves were the goal of this decision, in reality, these reasons are known only by The Great Omniscience.

At any rate, having established the existence of things, The Great Omniscience set about the development of beings. And following that, The Great Omniscience, being omniscient, knew that qualities must be established, and that there must be reasonable limits to the behavior of these beings in order that the integrity of their qualities be maintained.

In other words, Joshua, there must be rules, so that beings could exist peacefully around each other. If these rules were broken, some rules, anyway, something unintended might 
come into the world which would inevitably change the quality of life.

So The Great Omniscience made it known to the first people that they could eat plants, and seeds, and fruit for food-as much as they needed. You may have seen this written in the Book of Beginnings, Chapter 1, Verse 29. However, The Great Omniscience also made it known to the first people that there was something they should never eat, because in doing so the people would learn about good and evil, thus bringing evil into the world which The Great Omniscience had established and proclaimed to be good. The people were told, symbolically, to eat from the tree of life, but not from the tree of the knowledge of good and evil. This forbidden food would cause people to die. You may also have seen this, Joshua, written in the Book of Beginnings, in Chapter 2, Verses 9, 16-17.

Eventually, however, the people became curious. For whatever reason, the people ate the forbidden food. They killed an animal and ate it. That first act of killing filled the people with revulsion and horror. But when nothing seemed to happen right away, the people pushed the revulsion and horror to the backs of their minds, and the next time the killing was easier. Knowledge of evil had come into the world and, by contrast, conscious awareness of good.

The Great Omniscience was not pleased. The once peaceful earth became more and more violent. Finally, The Great Omniscience decided to send a great storm with wind and rain, and massive waves, to erase the evil from the earth. It seemed to The Great Omniscience, however, that one small group of people was relatively innocent. They had observed, but had not killed, and had not eaten themselves of the forbidden food. So The Great Omniscience provided them a safe place to ride out the storm, along with a male and female of every kind of animal. These people were called the Haon, or the righteous ones. When the storm abated, the Haon people and the animals came out. The earth was swept clear of everything. Nothing familiar was to be seen.
Naturally, the Haon people were grateful to have survived the storm, but they chose a strange and indiscriminate way to show their gratitude - they restored violence to the world by sacrificing some of the animals that The Great Omniscience had told them to save from the storm. When The Great Omniscience smelled the smoke of the burning sacrifice It said, 'The heart and imagination of humans is corrupt from their beginnings. I will take no more action to destroy in order to cleanse; I will continue the natural processes of nature. But all nature, all animals-all birds, all beasts, all fish, shall dread and fear humans. Since you are determined to eat flesh, I no longer forbid you, but as your ancestors were told in the beginning, as you eat of it you shall surely die.' This, Joshua, is written in the Book of Beginnings, in Chapter 8, Verses 20-22, and Chapter 9, Verses 2-5.

And it came to pass that many people on the earth began to eat more and more meat. They ate less and less plants. They began to think this was normal. And they began to get sick. And they surely began to die. They still do. They die of heart disease, and strokes, and cancer. They get more degenerative diseases... too much protein and their kidneys fail and their bones dissolve...too much fat and they get overweight and develop diabetes. The list goes on. But it has gone on for so long that many people have forgotten any other way.

Evil is magnified by the unspeakable ways, and numbers, animals are raised to provide meat. They are routinely given hormones and antibiotics to make them grow more or produce more and to try to prevent their stressful lives from killing them before they are up to prime. And some of these drugs end up in people who eat the meat or drink the milk or ingest other animal products. If you treated your pet animal the way most food animals are treated, you would be arrested for cruelty to animals. But food animals are not protected by these laws.

As if this were not enough, the raising of animals for food is environmentally destructive. Rain forests are cut for pasture, range lands suffer serious erosion, water is polluted, 
much water is needed for feed crops and processing, and raising animals for food is extremely energy intensive. It seems that the earth itself is not well. It begins to appear that humans are not good for the earth. Indeed, although humans need the earth, the earth does not need humans and would go right on without them.

Grandfather paused, and Joshua sat very still, thinking. Somehow the story seemed familiar, as though he had known it all along, but at the same time it seemed new and disturbing. Then Grandfather continued.

You know, Joshua, the fable says that eventually The Great Omniscience will set things right and the world will return to its origins, before the First Wrongdoing. According to the prophet Haiasi, wolves and lambs will live together, and leopards and lions will lie down with young animals such as kids and calves. The prophet says they will be led by a little child, and that carnivores will feed on plants and eat side by side with herbivores. Humans and animals will not fear each other. According to this prophet, the world will be filled with knowledge of The Great Omniscience, so there will be no more hurt or destruction. This is written in the Book of Haiasi, Chapter 11, Verses 6-9.

Of course, this is a fable, Joshua. Who can say if carnivores will really become herbivores? The message is for people. There are many, many people who say that permission was given to eat meat in the Book of Beginnings, which I mentioned earlier, so they continue to do so. But there are others who say that The Great Omniscience saw that people were inclined to do what they wished, and therefore knew that to forbid flesh-eating at that time would be fruitless. The people who feel that permission was not willingly given, but rather that an unalterable addiction was left to its own devices, think that the original plan of The Great Omniscience should be adhered to as much as is humanly possible under the circumstances, so they eschew flesheating. As health and environmental problems escalate, it may be that The Great Omnis- cience's original plan will eventually be obvious to everyone to be the best. But we are not there yet; it will take more time. And, in the end, there may still be some who do not understand.

When Grandfather finished speaking, the two of them sat quietly. The only sound was that of crickets and grasshoppers chirping, and birds singing and calling in the trees. Joshua thought about what Grandfather had said, and he listened to the gentle sounds around them, and Joshua, too, knew that it could be good.

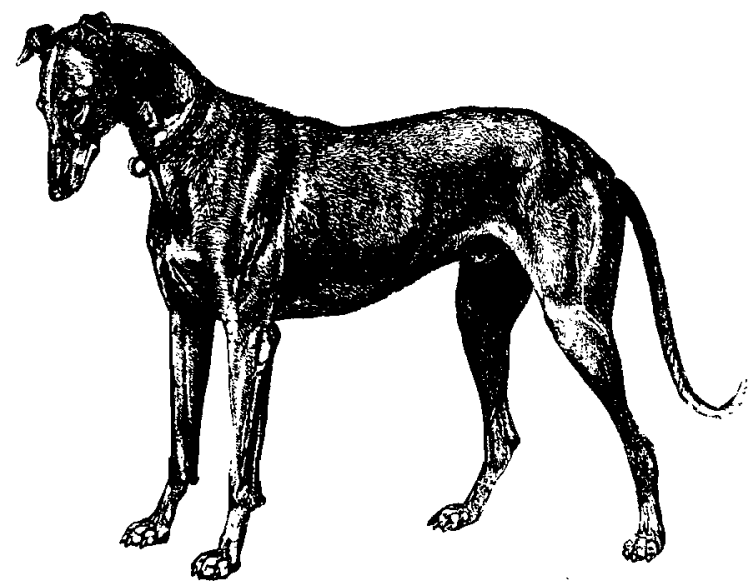

Albert Camus, in American Journals:

Their love of animals.... In Central Park a lady grazes a gazelle. In court the lady explains that the gazelle is a person.

"However, it doesn't speak," says the judge. "Yes, the language of goodness." 